\title{
Pengembangan Beras Jagung dan Penyusunan SOP Penanakan menggunakan Rice Cooker
}

\author{
Tjahja Muhandri dan Subarna \\ Departemen Ilmu dan Teknologi Pangan, FATETA - IPB Kampus IPB Darmaga, PO BOX 220, \\ Darmaga, Bogor. cahyomuhandri@yahoo.com \\ Diterima 13 Januari 2011/ Disetujui 9 Februari 2011
}

\begin{abstract}
Research on rice substitution has been done, but it is difficult in application. The objectives of this research were to study the corn rice technology and to design the standard operating procedure (SOP) of corn rice cooking. This research used P21 corn variety, polisher, breaker roll, shiver and rice cooker. Corns were crushed, polished, and shivered in to 5 sizes ( $>4 \mathrm{~mm}, 3.35-4 \mathrm{~mm}, 2.36-3.35 \mathrm{~mm}, 1.18-2.36$, dan $<1.18 \mathrm{~mm}$ ). A part of corn grits were cooked straightly, another part were soaked before cooking. The survey result showed that consumers preferred 1.18-2.36 mm corn grits. Corn grits of $<1.18 \mathrm{~mm}$ and 1.18-2.36 mm, can be cooked using rice cooker without pre-soaking. Corn grits of $>4 \mathrm{~mm}, 3.35-4 \mathrm{~mm}$, and 2.36-3.35 mm should be soaked before cooked using rice cooker. Nutrition content of corn grits were $79.08 \%$ of carbohydrates, $6.80 \%$ of protein, $1.1 \%$ of lipid, $15.48 \%$ of dietary fiber, $0.25 \%$ of ash, and $353.38 \mathrm{kcal}$ of calorie.

Keyword : corn rice, cooked, rice cooker
\end{abstract}

\section{PENDAHULUAN}

Kebutuhan akan alternatif pengganti beras merupakan faktor utama banyaknya penelitian yang dilakukan pada komoditas penghasil pati, khususnya jagung. Beragam tahap penelitian telah dilakukan namun hasilnya belum optimal. Kondisi ini disebabkan oleh fokus penelitian lebih banyak terpusat pada karakteristik kemudahan dan nilai tambah yang tinggi saja. Padahal, suatu produk tidak akan mampu menjadi alternatif makanan pokok jika proses pembuatannya menyebabkan harga produk tersebut menjadi mahal. Secara psikologis, masyarakat akan sulit menjadikan suatu produk sebagai makanan pokok jika harganya lebih mahal dari beras.

Penelitian makanan pokok sebagai subsitusi beras telah dilakukan. Tawali et al (2003) meneliti bassang (bubur jagung) instant. Sugiyono et al (200) meneliti nasi jagung instant, Raharjo et al (2003) meneliti tiwul instant, Tawali et al (2007) meneliti jagung sosoh pratanak (JSP) dan Koswara (2003) meneliti sweet potato flake. Proses pembuatan produk tersebut sulit dilakukan karena keterbatasan mesin dan peralatan di masyarakat. Disamping itu ada kendala pada kebiasaan konsumsi di masyarakat untuk produk sweet potato flake.

Penelitian ini bertujuan untuk mendapatkan teknologi pengolahan beras jagung yang tepat tanpa memaksakan produk akhirnya bersifat instant. Teknologi pengolahan beras jagung yang digunakan adalah dengan menggunakan rice cooker. Teknologi ini dipilih karena penggunaan rice cooker sudah sangat dikenal oleh masyarakat. Selain itu, teknologi yang digunakan dan produk yang dihasilkan dipilih agar harga produk tidak melebihi harga beras, namun aspek penyiapan (pemasakan) hingga menjadi produk siap santap tidak terlalu sulit.

Arah yang ingin dicapai adalah pengembangan beras jagung yang dapat ditanak dengan menggunakan rice cooker. Dengan pendekatan ini diharapkan biaya operasi dan harga jual produk lebih murah. 
Tujuan penelitian ini adalah : 1) melakukan optimasi dan penyusunan Standard Operating Procedures (SOP) penyosohan dan pembuatan grits jagung; 2) melakukan optimasi Standard Operating Procedures (SOP) penanakan nasi jagung dengan menggunakan rice cooker; 3) memproduksi prototype produk grits jagung dalam kemasan berikut analisis kandungan nutritional fact dan survei pasar.

\section{METODE KAJIAN}

\section{Bahan dan Alat}

Bahan-bahan yang digunakan terdiri dari jagung kuning varietas P21, air, dan bahan kimia yang digunakan untuk analisis kandungan zat gizi. Alat-alat yang digunakan terdiri dari disc mill, penyosoh (polisher), pengayak, rice cooker, baskom, kompor, panci, kain saring, pisau, penggaris, dan sendok pengaduk serta peralatan analisis kandungan zat gizi.

\section{Optimasi Penyosohan dan Pembuatan Grits Jagung}

Jagung pipil dipecah menggunakan breaker roll sehingga menghasilkan grits jagung. Hasil penggilingan disosoh dengan menggunakan alat penyosoh beras (abrasive polisher) untuk menghilangkan kulit biji dan lembaga yang masih menempel. Beras jagung yang telah mengalami penyosohan selanjutnya diayak dengan menggunakan pengayak manual. Pada tahap ini dilakukan optimasi ukuran fraksi beras jagung dengan menggunakan variasi ukuran pengayak. Variasi ukuran pengayak yang digunakan adalah $>4 \mathrm{~mm}, 3,35-4 \mathrm{~mm}, 2,36-3,35 \mathrm{~mm}, 1,18-2,36$, dan $<1,18 \mathrm{~mm}$. Beras jagung yang telah dihasilkan kemudian dianalisis rendemen, densitas kamba, dan distribusi ukurannya. Diagram alir pembuatan grits jagung dapat dilihat pada Gambar 1.

\section{Kajian Standard Operating Procedures (SOP) Penanakan}

Kajian SOP penanakan dilakukan dengan menggunakan rice cooker, penanakan dihentikan jika rice cooker menunjukkan off. Tahapan kajian SOP penanakan dilakukan sebagai berikut :

- Grit jagung dari semua ukuran, diambil 50 gram dan ditanak dengan perbandingan grit:air sebesar 1:1, 1:2, 1:3, 1:4, 1:5, 1:6, 1:7 dan 1:8. Hasil penanakan dianalisis secara organoleptik (dikunyah) dan dengan analisis tingkat gelatinisasi menggunakan mikroskop polarisasi.

- Perlakuan awal diberikan pada grit yang tidak matang pada proses penanakan di atas. Perlakuan ini berupa perendaman dengan air dingin dan air panas, ditiriskan kemudian ditanak dengan perbandingan grit:air sesuai hasil penanakan di atas. Hasil penanakan dianalisis secara organoleptik (dikunyah) dan dengan analisis tingkat gelatinisasi menggunakan mikroskop polarisasi.

- Langkah selanjutnya menanak grit dengan jumlah yang beragam yaitu 50, 80, 100, 150 dan $200 \mathrm{gr}$ dengan jumlah air tanak yang disesuaikan melalui metode trial and error. 


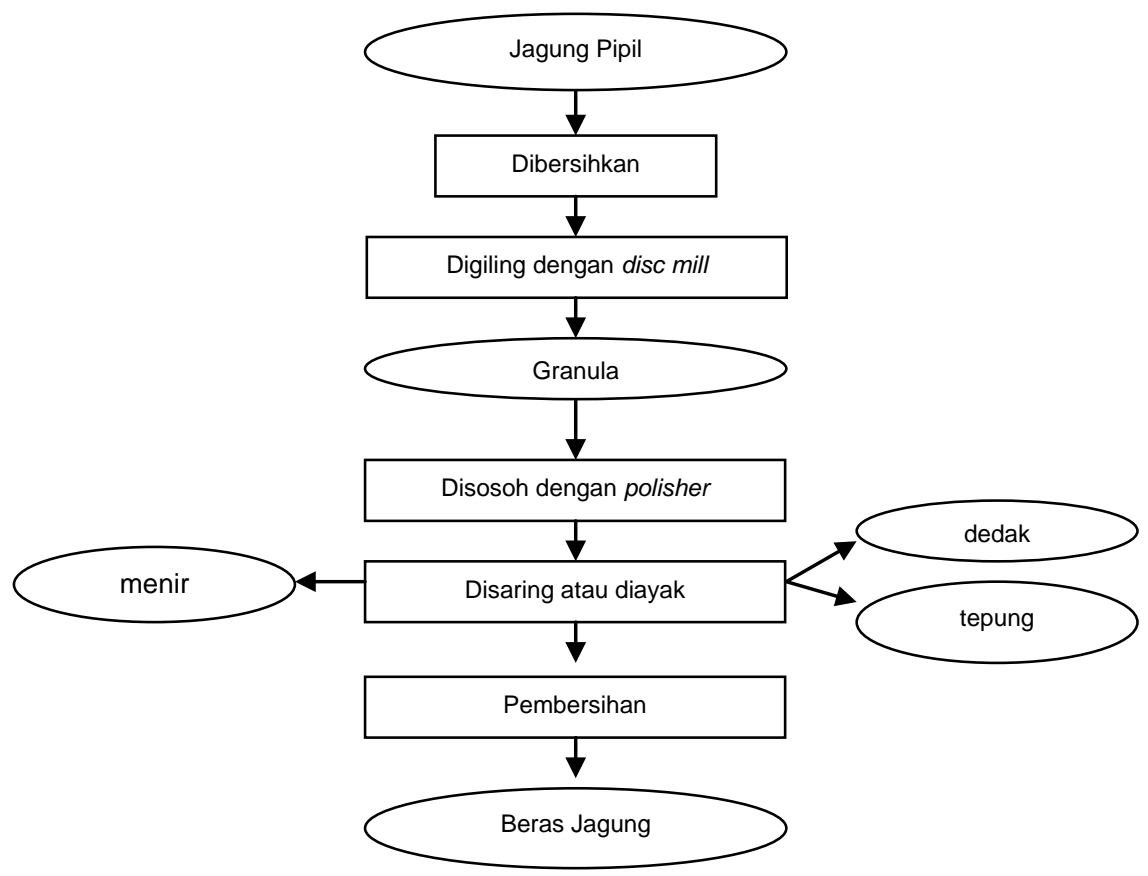

Gambar 1. Diagram alir pembuatan beras jagung

\section{Analisis Penerimaan Konsumen dan Kandungan Zat Gizi}

Analisis penerimaan yang dilakukan dalam penelitian ini yaitu uji rangking hedonik dengan parameter karakteristik keseluruhan produk (overall attributes). Jumlah panelis adalah 30 orang ibu rumah tangga. Analisis kandungan zat gizi dilakukan dengan metode sebagai berikut : Kadar Air Metode Oven Biasa (Apriyantono et al., 1989), Kadar Abu (Apriyantono et al., 1989), Kadar Protein Metode Kjeldahl Mikro (Apriyantono et al., 1989), Kadar Lemak Metode Soxhlet (AOAC, 1984), Kadar Karbohidrat by difference (AOAC, 1995), Kadar Serat Pangan Metode EnzimatikGravimetrik, Nilai Kalori Makanan (Almatsier, 2001).

\section{HASIL DAN PEMBAHASAN}

\section{Pembuatan Grit Jagung}

Pembuatan beras (grits) jagung dari jagung pipil dilakukan dengan menggunakan breaker roll. Proses ini dilakukan sebanyak tiga kali (tiga batch). Masingmasing batch menggunakan 20 kilogram jagung pipil. Grit kemudian disosoh dengan menggunakan alat penyosoh beras (abrasive polisher) untuk menghilangkan kulit biji dan lembaga yang masih menempel.

Proses pengayakan menghasilkan fraksi beras jagung dengan lima ukuran yang berbeda. Fraksi beras jagung ukuran $A$ adalah fraksi yang tidak lolos ayakan $4 \mathrm{~mm}$, sedangkan fraksi beras jagung ukuran $B$ adalah fraksi yang lolos ayakan $4 \mathrm{~mm}$ dan tidak lolos ayakan 3,35 mm. Fraksi beras jagung ukuran $\mathrm{C}$ adalah fraksi yang lolos ayakan $3,35 \mathrm{~mm}$ dan tidak lolos ayakan 2,36 $\mathrm{mm}$. Fraksi beras jagung ukuran $\mathrm{D}$ adalah fraksi yang lolos ayakan 2,36 $\mathrm{mm}$ dan tidak lolos ayakan 1,18 mm. Fraksi beras jagung ukuran $\mathrm{E}$ adalah fraksi yang lolos ayakan $1,18 \mathrm{~mm}$. Beras jagung kemudian dianalisis rendemen dan distribusi ukurannya. Hasil analisis rendemen dan distribusi ukuran grits dapat dilihat pada Tabel 1. Pada proses penggilingan, bagian jagung yang keras akan menjadi 
butiran-butiran dan bagian jagung yang lunak akan menjadi tepung. Hasil analisis distribusi ukuran grits menunjukkan bahwa fraksi beras jagung yang paling banyak dihasilkan adalah fraksi beras jagung $\mathrm{C}$ dengan ukuran $2,36-3,35 \mathrm{~mm}(47,37 \%)$.

Tabel 1. Persentase rendemen dan distribusi ukuran grits beras jagung

\begin{tabular}{lccccccc}
\hline & & & \multicolumn{5}{c}{ Distribusi Ukuran $(\%)$} \\
No. & $\begin{array}{c}\text { Grits } \\
\text { Jagung }\end{array}$ & $\begin{array}{c}\text { Rendemen } \\
(\%)\end{array}$ & $\mathrm{A}(\mathrm{mm})>$ & $\mathrm{B}(\mathrm{mm})$ & $\mathrm{C}(\mathrm{mm})$ & $\mathrm{D}(\mathrm{mm})$ & $\mathrm{E}(\mathrm{mm})$ \\
& & 4 & $3,35-4$ & $2,36-3,35$ & $1,18-2,36$ & $<1,18$ \\
\hline 1. & Batch 1 & 50,35 & 3,08 & 12,99 & 47,19 & 35,64 & 1,10 \\
2. & Batch 2 & 53,89 & 5,31 & 17,52 & 47,98 & 28,62 & 0,58 \\
3. Batch 3 & 52,05 & 2,75 & 9,39 & 46,94 & 40,18 & 0,73 \\
Rata-rata & 52,10 & 3,71 & 13,30 & 47,37 & 34,84 & 12,41 \\
\hline
\end{tabular}

\section{Kajian SOP Penanakan Grit (Beras) Jagung}

Kajian yang dilakukan untuk menentukan standard operating procedures (SOP) penanakan hanya dilakukan pada beras jagung dengan ukuran A ( $>4 \mathrm{~mm}), \mathrm{B}(3,35-4$ $\mathrm{mm}), C(2,36-3,35 \mathrm{~mm})$, dan $\mathrm{D}(1,18-2,36 \mathrm{~mm})$. Beras jagung dengan ukuran $E(<1,18$ $\mathrm{mm}$ ) tidak disertakan dalam penelitian ini karena ukurannya sangat kecil dan jauh berbeda dengan ukuran beras padi pada umumnya. Penanakan dilakukan dengan menggunakan grit sebanyak 50 gr. Hasil penanakan disajikan pada Tabel 2.

Hasil penanakan yang menunjukkan matang secara organoleptik, selanjutnya dianalisis kesempurnaan tingkat gelatinisasinya menggunakan mikroskop polarisasi. Foto disajikan pada Gambar 2. Nasi jagung ukuran A, B dan C belum tergelatinisasi sempurna yang ditandai dengan adanya granula pati yang masih berwarna merah biru, sehingga dapat dikatakan belum matang dengan sempurna.

Tabel 2. Hasil penanakan tanpa perlakuan awal

\begin{tabular}{cllll}
\hline $\begin{array}{c}\text { Perbandingan } \\
\text { grit jagung:air }\end{array}$ & $\begin{array}{c}\text { Grit ukuran A } \\
(>4 \mathrm{~mm})\end{array}$ & $\begin{array}{c}\text { Hasil Analisis Organoleptik (Subyektif) } \\
\text { Grit ukuran B } \\
(3,35-4 \mathrm{~mm})\end{array}$ & $\begin{array}{c}\text { Grit ukuran C } \\
(2,36-3,35 \mathrm{~mm})\end{array}$ & \multicolumn{1}{c}{$\begin{array}{c}\text { Grit ukuran D } \\
(1,18-2,36 \mathrm{~mm})\end{array}$} \\
\hline $1: 1$ & Mentah & Mentah & Mentah & Mentah \\
$1: 2$ & Mentah & Mentah & Mentah & Mentah \\
$1: 3$ & Mentah & Mentah & Mentah & Matang (kletis) \\
$1: 4$ & Mentah & Mentah & Matang (kletis) & Matang \\
$1: 5$ & Matang (kletis) & Matang (kletis) & Matang* & Matang (berair) \\
$1: 6$ & Matang (kletis) & Matang (kletis) & Matang (lembek) & - \\
$1: 7$ & Matang* & Matang* & - & - \\
$1: 8$ & Matang (lembek) & Matang (lembek) & - & - \\
\hline
\end{tabular}

Keterangan :- Tidak dilakukan * Matang secara organoleptik 


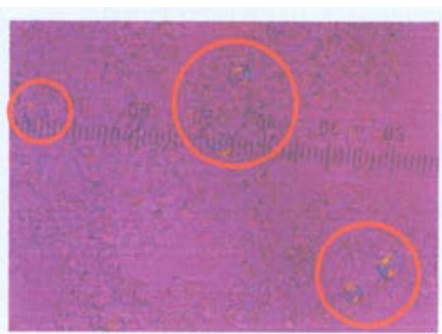

1.a. Nasi Jagung A

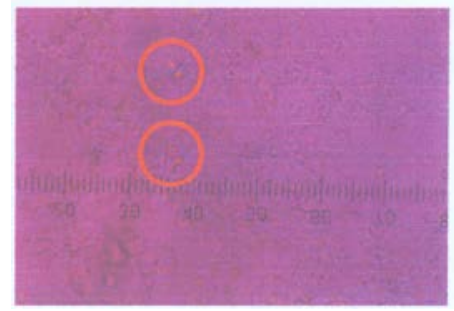

1.c. Nasi Jagung C

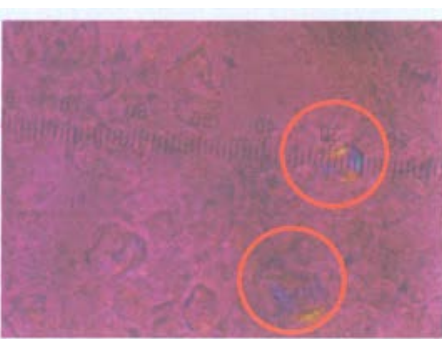

1.b. Nasi Jagung B

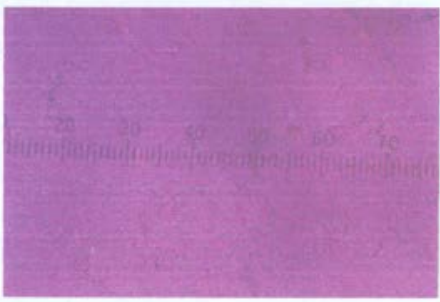

1.d. Nasi Jagung D

Gambar 2. Foto mikroskop polarisasi nasi jagung

Energi pemanasan pada penanakan belum cukup untuk menyebabkan seluruh granula pati tergelatinisasi. Menurut Muramatsu et al (2006) untuk menghasilkan tingkat gelatinisasi yang sempurna dibutuhkan penetrasi dan distribusi air secara menyeluruh ke dalam biji jagung. Menurut Belitz dan Grosch (1999) proses gelatinisasi dapat terjadi bila granula pati diberi air yang berlebih dan diikuti oleh pemanasan. Oleh karena itu dibutuhkan perlakuan awal (perendaman) untuk grit jagung ukuran A, B dan C.

Tabel 3 Penanakan untuk grit jagung ukuran $A, B, C$ dan D

\begin{tabular}{|c|c|c|}
\hline \multirow{2}{*}{$\begin{array}{l}\text { Ukuran Grit } \\
\text { Jagung }\end{array}$} & \multicolumn{2}{|c|}{ Proses Penanakan } \\
\hline & Perbandingan Grit:Air & Perlakuan Awal \\
\hline A & $1: 7$ & $\begin{array}{l}\text {-Perendaman air dingin } 5 \text { jam } \\
\text {-Perendaman air panas } 60 \text { menit }\end{array}$ \\
\hline B & $1: 7$ & $\begin{array}{l}\text {-Perendaman air dingin } 4 \text { jam } \\
\text {-Perendaman air panas } 50 \text { menit }\end{array}$ \\
\hline C & $1: 5$ & $\begin{array}{l}\text {-Perendaman air dingin } 3 \text { jam } \\
\text {-Perendaman air panas } 30 \text { menit }\end{array}$ \\
\hline D & $1: 4$ & Tanpa perlakuan awal \\
\hline
\end{tabular}

Perendaman awal dilakukan dengan air dingin (suhu ruang) dengan lama yang bervariasi yaitu 1, 2, 3, 4, dan 5 jam. Perlakuan perendaman air panas (direndam air mendidih dan dibiarkan) dilakukan dengan variasi 10,20, 30, 40, 50 dan 60 menit. Grit jagung sebanyak $50 \mathrm{gr}$ direndam, ditiriskan dan ditanak dengan perbandingan grit:air 1:5 untuk ukuran $C$ dan 1:7 untuk ukuran $B$ dan $A$. Kematangan yang sempurna diperoleh dari perlakuan seperti yang disajikan pada Tabel 3. 
Tahap terakhir yaitu trial untuk memperoleh perbandingan grit:air dengan berbagai berat grit jagung. Hasil penanakan yang optimal diperoleh dengan perbandingan seperti disajikan pada Tabel 4.

Tabel 4 Jumlah air penanakan yang optimal untuk berbagai berat grit

\begin{tabular}{ccccc}
\hline Jumlah Grit & & \multicolumn{3}{c}{ Jumlah Air untuk Penanakan } \\
Jagung (gram) & Grit Ukuran A & Grit Ukuran A & Grit Ukuran A & Grit Ukuran A \\
\hline 50 & $350 \mathrm{ml}$ & $350 \mathrm{ml}$ & $250 \mathrm{ml}$ & $200 \mathrm{ml}$ \\
80 & $400 \mathrm{ml}$ & $400 \mathrm{ml}$ & $300 \mathrm{ml}$ & $250 \mathrm{ml}$ \\
100 & $450 \mathrm{ml}$ & $450 \mathrm{ml}$ & $350 \mathrm{ml}$ & $300 \mathrm{ml}$ \\
150 & $500 \mathrm{ml}$ & $500 \mathrm{ml}$ & $400 \mathrm{ml}$ & $400 \mathrm{ml}$ \\
200 & $650 \mathrm{ml}$ & $650 \mathrm{ml}$ & $500 \mathrm{ml}$ & $500 \mathrm{ml}$ \\
\hline
\end{tabular}

Berdasarkan informasi data di atas, SOP penanakan penanakan grit untuk menghasilkan nasi jagung yang matang sempurna (optimal) jika menggunakan rice cooker disajikan pada Gambar 2.

\section{Analisis Penerimaan Konsumen dan Kandungan Gizi Grit (Beras) Jagung}

Analisis penerimaan konsumen dilakukan dengan menyajikan nasi jagung dari keempat ukuran (A, B, C dan D). Hasil survey menunjukkan bahwa $13.33 \%$ responden menyukai nasi jagung dari grit ukuran $\mathrm{B}, 26.67 \%$ menyukai nasi jagung dari grit ukuran $\mathrm{C}$ dan $60 \%$ responden menyukai nasi jagung dari grit ukuran $\mathrm{D}$. Tidak ada responden yang menyukai nasi jagung dari grit ukuran A. hal ini menunjukkan bahwa grit (beras) jagung ukuran $\mathrm{D}$ berpotensi lebih besar untuk dikembangkan menjadi produk substitusi beras.

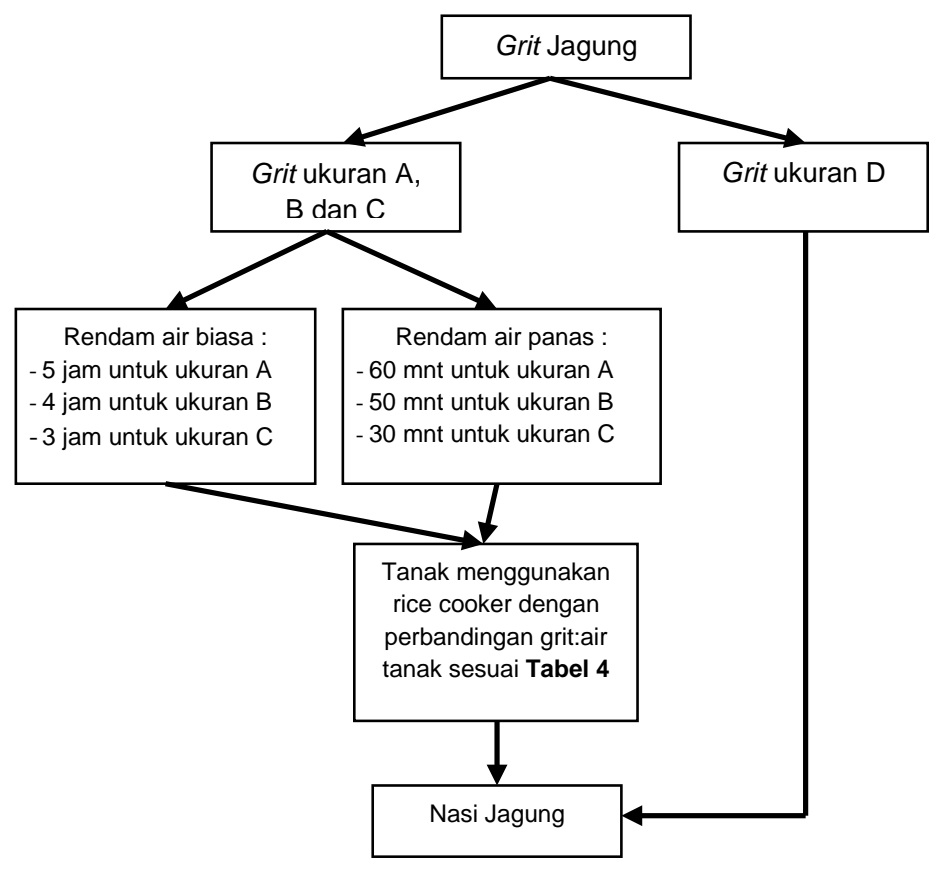

Gambar 3. Standard operating procedure (SOP) penanakan nasi jagung

Grit jagung ukuran D dianalisis kandungan gizi dan kalorinya. Hasil analisis kandungan zat gizi dan nilai kalori adalah sebagai berikut : kadar air $12,78 \%$, kadar abu $0,25 \%$, kadar protein $6,80 \%$, kadar lemak $1,10 \%$, karbohidrat $79,08 \%$, serat pangan 
6,67\% dan nilai kalori untuk 100 gram yaitu 353,38 kkal. Girt (beras) jagung yang telah dikemas dapat dilihat pada Gambar 4.

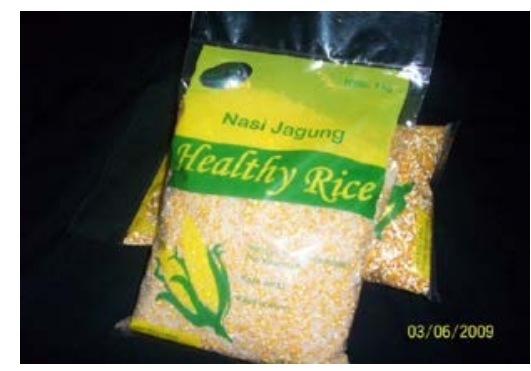

Gambar 4. Beras jagung dalam kemasan

\section{SIMPULAN}

Grit (beras) jagung diperoleh dari proses pemecahan, penyosohan, pengayakan dan pembuangan kotoran. Grit jagung ukuran $\mathrm{D}(1,18-2,36 \mathrm{~mm})$ tidak memerlukan perlakuan awal untuk penanakan dengan menggunakan rice cooker. Grit ukuran A ( $>4$ $\mathrm{mm})$, ukuran $B(3,35-4 \mathrm{~mm})$ dan ukuran $C(2,36-3,35 \mathrm{~mm})$ memerlukan perlakuan awal berupa perendaman air suhu normal atau air panas.

Konsumen lebih menyukai nasi jagung dari grit (beras) jagung ukuran $D(1,18-2,36$ $\mathrm{mm}$ ). Tidak ada konsumen yang menyukai nasi jagung dari grit ukuran A. Kandungan zat gizi dan nilai kalori nasi jagung ukuran $\mathrm{D}$ adalah kadar air $12,78 \%$, kadar abu 0,25\%, kadar protein $6,80 \%$, kadar lemak $1,10 \%$, karbohidrat $79,08 \%$, serat pangan $6,67 \%$ dan nilai kalori untuk 100 gram adalah 353,38 kkal.

\section{DAFTAR PUSTAKA}

Almatsier S. 2001. Prinsip Dasar Ilmu Gizi. Gramedia Utama, Jakarta.

Apriyantono A, Fardiaz D, Puspitasari NL, Yasni S, Budijanto S. 1989. Analisis Pangan. IPB Press, Bogor.

AOAC. 1984. Offical Methods of Analysis of the Association Analytical Chemistry. AOAC International, Washington DC.

AOAC. 1995. Offical Methods of Analysis of the Association Analytical Chemistry. AOAC International, Maryland.

Belitz HD, Grosch W. 1999. Food Chemistry. Spinger Verlage, Berlin.

Koswara S. 2003. Optimasi Teknologi Pengolahan Sweet Potato Flakes. RUSNAS Diversifikasi Pangan Pokok.

Muramatsu Y, Tagawa A, Sakaguchi E, Kasai T. 2006. Water Absorption Characteristic and Volume Changes of Milled and Brown Rice During Soaking. Cereal Chem. 83(6): 624-631.

Raharjo S, Supartono W, Tranggono. 2003. Optimasi Teknologi Cassava Instant. RUSNAS Diversifikasi Pangan Pokok.

Sugiyono, Hariyadi P, Soekarto ST, Adawiyah DR, Supriadi A. 2003. Optimasi Teknologi Pengolahan Beras Jagung Instant. RUSNAS Diversifikasi Pangan Pokok.

Tawali AB, Laga A, Mahendratta M. 2003. Pengembangan Produk "Bassang”. RUSNAS Diversifikasi Pangan Pokok. 